\title{
Development of anti-reflecting surfaces based on Si micropyramids and wet-chemically etched Si nanowire arrays
}

\author{
A.A.Druzhinin, V.Y.Yerokhov, S.I.Nichkalo, O.Y.Ostapiv \\ Lviv Polytechnic National University, 12 S.Bandera Str., \\ 79013 Lviv, Ukraine
}

Received March 29, 2018

\begin{abstract}
In this paper experimental results on study of optical properties of Si wafers with surface textures in form of Si random pyramids, Si nanowire arrays, and pyramidal Si combined with Si nanowire arrays are presented. It is shown that the use of the metal-assisted chemical etching method allows to fabricate an array of Si nanowires, and a complex structure composed of Si pyramids with nanotextured side faces which possess a high degree of anti-reflecting ability. Experimental results of the absorbance and reflectance spectra measuring demonstrated that in comparison with other textures, the structures with nanotextured pyramids' side faces exhibit the highest absorption $(\sim 98 \%)$ and lowest reflection values $(\sim 1 \%)$ in all range of wavelength $(300-1100 \mathrm{~nm})$. The concept of a complex structure combining the advantages of pyramids and Si nanowires to achieve the omnidirectional light absorption and overcome the directional dependence of photovoltaic performance is discussed.
\end{abstract}

Keywords: silicon nanowire, absorption, reflection, solar cell, metal-assisted chemical etching.

Представлены экспериментальные результаты исследования оптических свойств пластин Si с поверхностными текстурами в виде случайных пирамид $\mathrm{Si}$, массивов нанопроволок $\mathrm{Si}$, а также пирамид в сочетании с массивами нанопроволок Si. Показано, что использование метода металл-каталитического химического травления позволяет получить массивы нанопроволок Si и сложную структуру, содержащую пирамиды с нанотекстурированными боковыми гранями, которые обладают высокими антиотражающими свойствами. Экспериментальные результаты измерения спектров поглощения и отражения показали, что по сравнению с другими текстурами для структур пирамид с нанотекстурированными боковыми гранями выявлено наибольшее поглощение $(\sim 98 \%)$ и наименьшее отражение ( 1 \%) во всем диапазоне длин волн (300-1100 нм). Обсуждается концепция сложной структуры, которая бы сочетала преимущества пирамид и нанопроводов Si с целью достижения всенаправленного поглощения света и преодоления зависимости фотоэлектрической әффективности от угла падения солнечных лучей.

Розроблення антивідбивних поверхонь на основі мікропірамід $\mathrm{Si}$ та масивів нанодротів $\mathrm{Si}$, отриманих методом рідкого хімічного травлення. А.О.Дружинін, В.Ю.Срохов, С.І.Нічкало, О.Ю.Остапів.

Представлено експериментальні результати дослідження оптичних властивостей пластин Si з поверхневими текстурами у вигляді випадкових пірамід Si, масивів нанодротів Si та пірамід у поєднанні з масивами нанодротів Si. Показано, що використання методу метал-каталітичного хімічного травлення дозволяє отримати масиви нанодротів $\mathrm{Si}$ та складну структуру, що містить піраміди з нанотекстурованими бічними гранями, які володіють високими антивідбивними властивостями. Експериментальні результати вимірювання спектрів поглинання та відбивання показали, що у порівнянні з іншими 
текстурами для структур пірамід з нанотекстурованими бічними гранями виявлено найбільше поглинання ( 98\%) і найменше відбивання ( 1 \%) у всьому діапазоні довжин хвиль (300-1100 нм). Обговорюється концепція складної структури, яка б поєднувала переваги пірамід і нанодротів Si з метою досягнення всенаправленого поглинання світла та подолання залежності фотоелектричної ефективності від кута падіння сонячних променів.

\section{Introduction}

Today silicon-based solar cells (SC) remain the basis of current photovoltaic (PV) industry due to the abundance of $\mathrm{Si}$ and high total efficiency of photocells [1-5]. However, high reflective index of $\mathrm{Si}$ causes the reflection of more than $30 \%$ of incident light. This leads to a reduction of photoconversion efficiency of the Si-PV devices, as a result. For traditional Si wafer-based $\mathrm{SC}$, the pyramidal or inverted pyramidal structures were generally constructed on $\mathrm{Si}$ surface to reduce the reflection loss of incident light and to increase the light absorption [6, 7]. However, such microstructured surfaces are not able to reduce reflectance below $10 \%$ [8-11]. The antireflecting coating layers $\left(\mathrm{Si}_{3} \mathrm{~N}_{4}, \mathrm{MgF}_{2}, \mathrm{Si}_{3} \mathrm{~N}_{4} / \mathrm{MgF}_{2}\right.$ etc. $)$ are also applied to suppress light reflection of microtextured surface, but they suffer from destructive interference of reflected light and lead to a narrowing of the solar spectrum of absorbed photons as a result [12]. In this regard, the nanotexturing of Si wafer surface is widely studied to reach maximum values of the absorption coefficient and to reduce reflection in a wide spectral range, improving the efficiency of SCs [13].

One dimensional nanostructures, such as Si nanowires (SiNWs) are widely considered as a promising material for high-performance devices due to their unique structural, electrical, thermoelectric properties in addition to their compatibility with current Sibased microelectronics [14-22]. Recent studies on the optical characteristics of SiNWs demonstrate their promising applications in SC [23-30]. SiNWs are long enough to absorb most of incident light, and their small diameters provide a short collection length for excited carriers in a direction normal to the light absorption. Unlike bulk Si with its indirect optical band gap of $1.12 \mathrm{eV}$ and low absorption coefficient of $10^{4} \mathrm{~cm}^{-1}$, the optical band gap of SiNWs can be varied between $1.1 \mathrm{eV}$ and $3.5 \mathrm{eV}$ by decreasing SiNW diameter between $7 \mathrm{~nm}$ and $1.3 \mathrm{~nm}$, respectively [31]. Several research groups showed that in the near UVvisible-near IR region optical reflectance of
SiNWs is one to two orders of magnitude lower than Si $[23,24,29,32,33]$. However, such structures are effective the best under direct sunlight illumination, and could not face the sun at the appropriate angle from morning to evening [34]. At the same time, the use of sun-tracking systems for the purpose of receiving direct light illumination is not costeffective for practical applications. The concept of a complex structure combining the advantages of pyramids and SiNWs might help to achieve the omnidirectional light absorption and overcome the directional dependence of PV performance [34]. Realization of this concept predicts utilizing of traditional alkaline texturing of $\mathrm{Si}$ wafer to produce the pyramidal $\mathrm{Si}$, and the metal-assisted chemical etching (MACE) to fabricate SiNWs on the side faces of pyramids. The use of MACE method for fabricating of SiNWs was motivated by its simplicity, good cost-efficiency, versatility, and ability to control various parameters, e.g., cross-section, shape, diameter, length, orientation [33, 35-37]. In contrast, the crystallographic orientation of SiNWs obtained by other growth technique, e.g. vapour-liquid-solid (VLS), depends upon the nanowire's diameter [38-40]. Moreover, the crystalline quality of SiNWs produced by MACE method generally is high, their surfaces are typically rougher than VLS-grown NWs, and they demonstrate higher SC performance over VLS-grown SiNWs, as a result $[36,41]$.

In this paper we present experimental results on study of optical properties of $\mathrm{Si}$ wafers with various surface textures, i.e. random Si pyramids, SiNW arrays, and pyramidal Si combined with SiNW arrays, in terms to develop a material with lowest reflectivity and highest light absorption over a wide solar spectral range.

\section{Experimental}

Boron-doped single crystalline $p$-type Si (100) and Si (111) wafers with resistivities of $0.3-1 \Omega \cdot \mathrm{cm}$ were used as the starting materials. The wafers were cut into $2 \times 2 \mathrm{~cm}^{2}$ pieces, cleaned in acetone, isopropyl alcohol (IPA), and deionized (DI) water for $20 \mathrm{~min}$ at room temperature. Afterwards, samples 


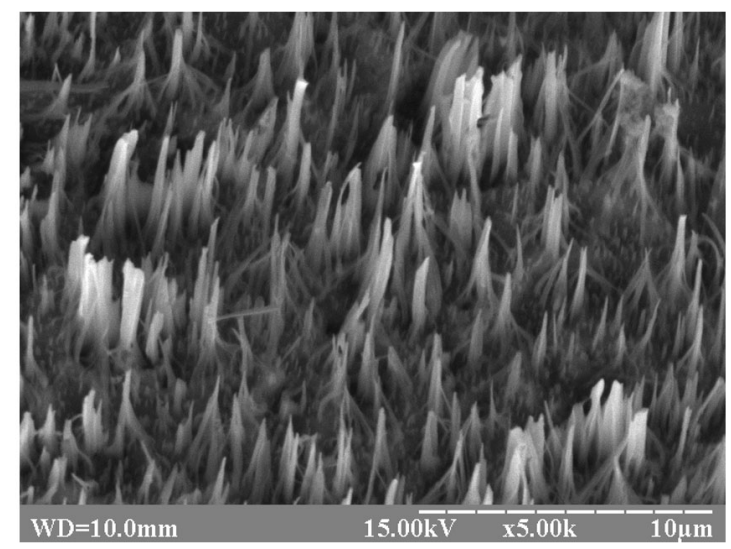

Fig. 1. Bird's-eye view SEM image of Si wafer after $10 \mathrm{~min}$ of Ag-assisted chemical etching in $\mathrm{HF}: \mathrm{H}_{2} \mathrm{O}_{2}: \mathrm{H}_{2} \mathrm{O}$ (v:v:v=4:1:4) solution at room temperature.

were dipped in the mixed solution of $\mathrm{NH}_{4} \mathrm{OH}$ $(30 \%), \mathrm{H}_{2} \mathrm{O}_{2}(35 \%)$ and DI water $(1: 1: 5)$ at $70^{\circ} \mathrm{C}$ for $10 \mathrm{~min}$ to remove any organic residues. In order to obtain an efficient anti-reflecting surface with a maximum absorption and the least possible reflection for possible use in photovoltaics, three different textures on the Si surface were made and examined.

The first texture in form of SiNW arrays was prepared through metal-assisted etching of Si-(111) wafer, accompanied by the following steps. Clean square Si-wafer samples were dipped in a solution containing $5 \mathrm{M}$ of hydrofluoric acid (HF) and $2 \mathrm{mM}$ of silver nitrate $\left(\mathrm{AgNO}_{3}\right)$ for $2 \mathrm{~min}$ at room temperature. This resulted in a deposition of $\mathrm{Ag}$ particles on the Si surface. Then, samples were rinsed by DI water for $10 \mathrm{~s}$, and immersed in the etchant solution $\mathrm{HF}(40 \%)+\mathrm{H}_{2} \mathrm{O}_{2}(35 \%)+\mathrm{H}_{2} \mathrm{O}$

(v:v:v=4:1:4) at room temperature for

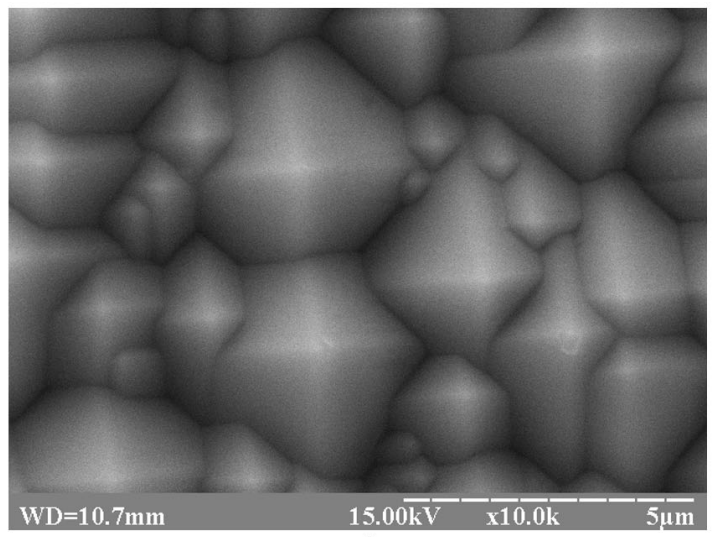

a)
10 min. After etching process, samples were immersed in a mixed solution of $\mathrm{NH}_{4} \mathrm{OH}$ and $\mathrm{H}_{2} \mathrm{O}_{2}$ (v:v $=3: 1$ ) at room temperature for $10 \mathrm{~min}$ to remove $\mathrm{Ag}$ residues. Prepared samples were rinsed with DI water for $10 \mathrm{~min}$ and dried.

The second texture, namely pyramidal, was fabricated by anisotropic etching of $\mathrm{Si}$ (100) wafer in a mixed solution of potassium hydroxide $(\mathrm{KOH})(9$ wt. \%) and acetic acid $(5$ vol. $\%)$ at $75^{\circ} \mathrm{C}$ for $10 \mathrm{~min}$. The pyramidal Si samples were then immersed in dilute hydrochloric acid $(\mathrm{HCl})$ for $10 \mathrm{~min}$ and hydrofluoric acid for $5 \mathrm{~min}$ to remove any residue $\mathrm{KOH}$ and $\mathrm{SiO}_{2}$, respectively. Finally, pyramid-textured Si samples were rinsed with DI water for $20 \mathrm{~min}$ at room temperature and dried.

The third texture was obtained by nanotexturing of the side faces of Si pyramids through MACE method. First, Ag particles were deposited on precleaned pyramidtextured $\mathrm{Si}$ wafers by immersing samples in a solution of $0.14 \mathrm{M} \mathrm{HF}$ and $0.5 \mathrm{mM} \mathrm{AgNO}_{3}$ for $7 \mathrm{~min}$ at room temperature, and then rinsed by DI water for $10 \mathrm{~s}$. Subsequently, pyramidtextured Si samples covered by $\mathrm{Ag}$ nanoseeds were immersed in the mixed etching solution of $\mathrm{HF}(40 \%), \mathrm{H}_{2} \mathrm{O}_{2}(35 \%)$, and DI water $(\mathrm{v}: \mathrm{v}: \mathrm{v}=4: 1: 4)$ at room temperature for 12 min. Then, all samples were immersed in a mixed solution $\mathrm{NH}_{4} \mathrm{OH}+\mathrm{H}_{2} \mathrm{O}_{2}(\mathrm{v}: \mathrm{v}=3: 1)$ at room temperature for $10 \mathrm{~min}$ to remove the residual $\mathrm{Ag}$ on their surface.

The fabricated textured Si samples were characterized by using a SELMI 106I scanning electron microscope (SEM). Absorbance and reflectance spectra were measured by Shimadzu UV-3101PC spectrophotometer at the wavelength ranging from 300 to $1100 \mathrm{~nm}$.

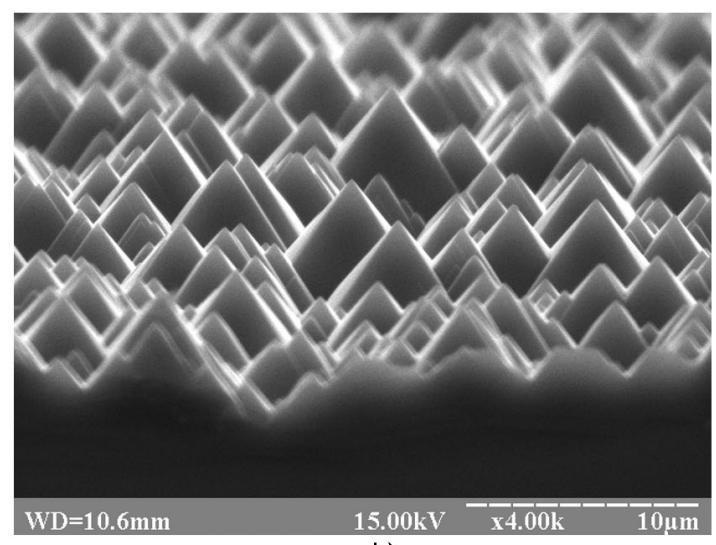

b)

Fig. 2. Top-view (a) and cross-section view (b) SEM images of random Si pyramids formed as a result of etching of Si wafer in a solution of $\mathrm{KOH}(9 \%)$ and acetic acid (5\%) at $75^{\circ} \mathrm{C}$ for 10 min. 


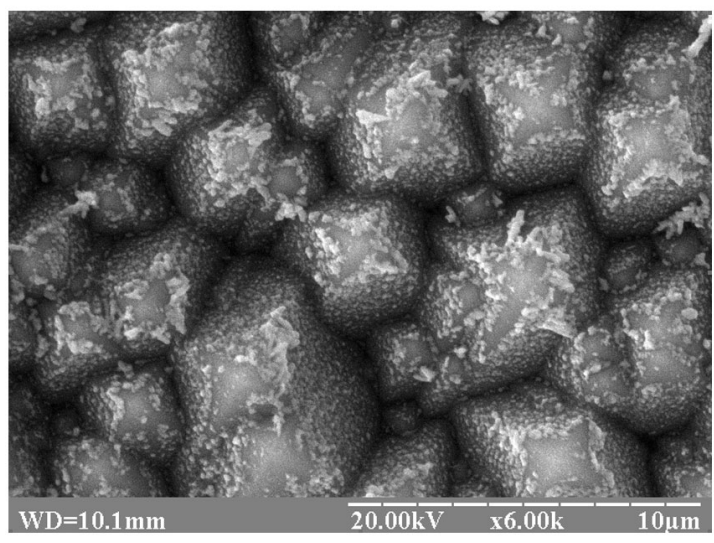

Fig. 3. Top-view SEM image of pyramidal Si wafer with deposited $\mathrm{Ag}$ nanoseeds after immersing in a solution of $0.14 \mathrm{M} \mathrm{HF}+0.5 \mathrm{mM}$ $\mathrm{AgNO}_{3}$ for $7 \mathrm{~min}$ at room temperature.

\section{Results and discussion}

Fig. 1 shows the SEM image of Si wafer after $10 \mathrm{~min}$ of Ag-assisted chemical etching in $\mathrm{HF}+\mathrm{H}_{2} \mathrm{O}_{2}+\mathrm{H}_{2} \mathrm{O}$ solution at room temperature. As a result, vertically aligned SiNW arrays were formed on Si surface. As it could be seen in Fig. 1, the NWs are preferentially cone-shaped with diameters ranging from $100 \mathrm{~nm}$ to $500 \mathrm{~nm}$, and an average height of about $4 \mu \mathrm{m}$.

Shown in Fig. 2a-b are the top-view and cross-section view SEM images of random Si pyramids formed as a result of etching of $\mathrm{Si}$ wafer in $\mathrm{KOH}$-based solution at $75^{\circ} \mathrm{C}$ for $10 \mathrm{~min}$. As we see, the average size of pyramids doesn't exceed $5 \mu \mathrm{m}$ at the bottom.

Fig. 3 shows the top-view SEM image of pyramid-textured $\mathrm{Si}$ wafers with predeposited $\mathrm{Ag}$ nanoseeds after immersing samples in a solution of $0.14 \mathrm{M} \mathrm{HF} / 0.5 \mathrm{mM} \mathrm{AgNO}_{3}$ for $7 \mathrm{~min}$ at room temperature. Consequently, chemical treatment of pyramidal samples covered by $\mathrm{Ag}$ nanoseeds in etching solution of $\mathrm{HF}(40 \%)+\mathrm{H}_{2} \mathrm{O}_{2}(35 \%)+\mathrm{H}_{2} \mathrm{O}$ $=4: 1: 4$ at room temperature for $12 \mathrm{~min}$ revealed to the formation of $\langle 111\rangle$-oriented SiNWs (Fig. 4). As it could be seen, SiNWs were etched normally to the surface planes of Si pyramids.

As it follows from [34, 42], the rough SiNWs on side faces of micropyramids predicted to have a strong absorption and extremely low reflection ability. This suggestion confirmed by our experimental results of measurement of absorbance (Fig. 5a) and reflectance spectra (Fig. 5b) for Si wafer samples with various surface morphologies. It was found that in comparison to other

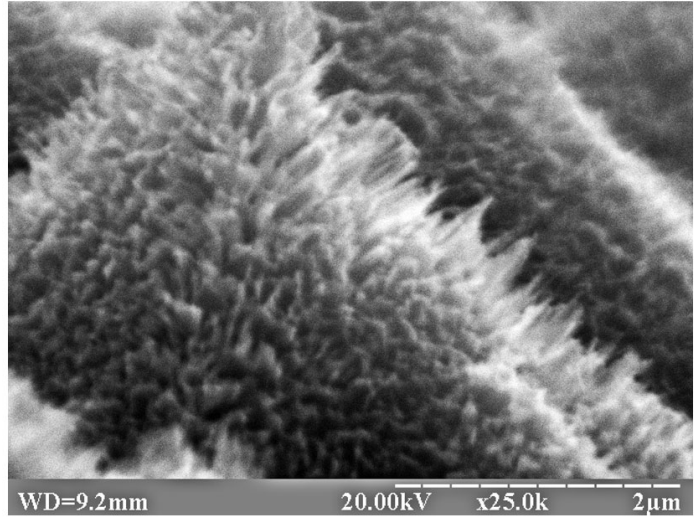

Fig. 4. Cross-section view SEM image of Si micropyramids textured by SiNWs after etching in $\mathrm{HF}(40 \%): \mathrm{H}_{2} \mathrm{O}_{2}(35 \%): \mathrm{H}_{2} \mathrm{O}(4: 1: 4)$ at room temperature for $12 \mathrm{~min}$.

textures, the pyramidal Si samples textured by SiNW arrays demonstrate a highest value of light absorption, more than $98 \%$, whereas for a non-textured $\mathrm{Si}$ wafer and a pyramid-textured $\mathrm{Si}$ this value found to be typical, $60 \%$ and $85 \%$, respectively (see Fig. 5a). In turn, a high absorption value of about $95 \%$ was found for Si-wafer samples with SiNW-texture. Such a high absorption could be explained in terms of the specific geometry of SiNWs, which are cone-shaped (see Fig. 1). According to [9], compared with planar thin film and NWs with uniform diameters, the cone-shaped Si nanostructures show improved absorption because of a gradual increase of the effective refractive index from the Si surface to air. On the other hand, in aperiodic SiNWs array the absorption at long wave-length regime is not decreased, unlike periodic one, in which calculated absorbance for early bandedge photons dwarfs due to the significant transmission loss [43]. Moreover, it was show that optimization of aperiodic NWs by using a random walk algorithm with transfer matrix method reveal to an over $100 \%$ enhancement factor in PV efficiency compared to the periodic counterparts [43].

Fig. 5b compares the optical reflection between various textures made on the surface of Si wafer samples. In contrast to pyramidal $\mathrm{Si}$ and SiNW arrays, the texture of SiNWs on the side faces of $\mathrm{Si} \mathrm{mi}-$ cropyramids possess a lowest reflection ability $(<1 \%)$ in all optical spectral range of wavelength. For the record, the low reflection value (about $4 \%$ ) was observed for SiNW arrays, as well. These findings confirm the assertion that vertically aligned 

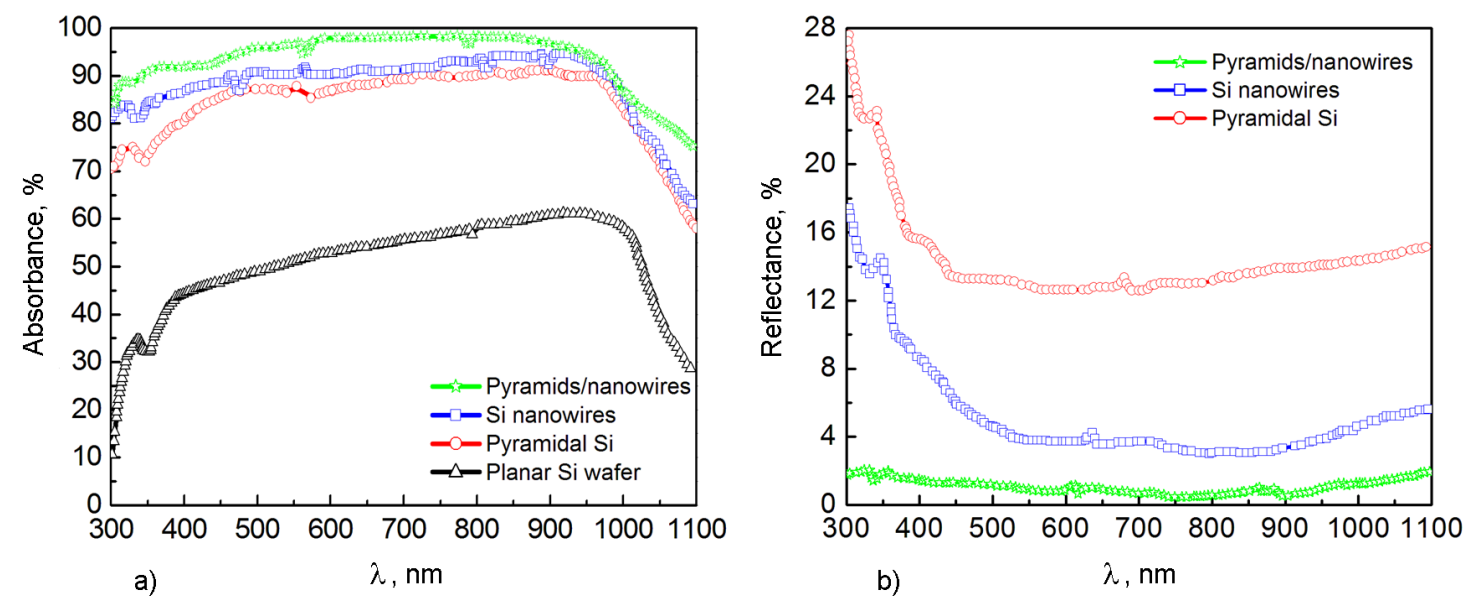

Fig. 5. Optical characteristics measured for Si wafer samples with various surface texture: a) Absorbance spectra for pyramid-textured Si, SiNW arrays, Si pyramids/SiNWs, and planar Si wafer (plotted as a reference); b) reflectance spectra for pyramid-textured Si, SiNW arrays, Si pyramids/SiNWs.

NWs with random position or diameter can also achieve similar low reflectance and high absorption as the ordered NWs with uniform diameter [44]. Notably, the random diameters of NW arrays lead to different broadened resonant frequencies which give rise to absorption enhancement [43,44]. While the absorption at the original offresonance frequency is enhanced, the original resonance frequency maintains high, caused by multiple scattering induced by the random arrangement or diameter of NWs. In other words, aperiodic SiNWs demonstrate suppress of light reflection similar to the random pyramid texture. Therefore, using MACE method we fabricated nonsymmetric nanostructures that can reach the Lambertian limit in absorbance through increasing the optical path length, as it was theoretically predicted in [9]. From the practical point of view it makes possible to reduce the cost of Si solar cells significantly by decreasing the total mass of Si.

\section{Conclusions}

The metal-assisted chemical etching is a simple, versatile and flexible method, which allows to fabricate Si nanostructures on the surface of Si wafer with good anti-reflecting properties. By using this method, an array of SiNWs, and a complex structure composed of Si pyramids with nanotextured side faces have been produced on Si wafers. The structures with nanotextured pyramids' side faces show a strong absorption (>98\%) and extremely low reflection $(<1 \%)$ in all range of wavelength $(300-1100 \mathrm{~nm})$. At the same time, for a non-textured and pyramid- textured Si wafers these values found to be typical. Low reflection value of about $4 \%$ was also observed for SiNW arrays. Thus, such nanotextured Si-based materials in form of Si micropyramids and SiNWs might exhibit better omnidirectional light-trapping ability due to multiple reflections resulting in enhanced optical characteristics, and will find a wide variety of significant applications in solar cells, photodetectors, and other optoelectronic devices.

\section{References}

1. J.Zhao, A.Wang, M.A.Green et al., Appl. Phys. Lett., 73, 1991 (1998).

2. V.Yu.Yerokhov, I.I.Melnyk, Sol.-State Electr., 42, 883 (1998).

3. M.A.Green, Adv. Mater., 13, 1019 (2001).

4. V.Y.Yerokhov, R.Hezel, M.Lipinski et al., Solar Ener. Mater. Solar Cells, 72, 291 (2002).

5. R.M.Swanson, Progr. Photovolt. Res. Appl., 14, 443 (2006).

6. C.H.Sun, W.L.Min, N.C.Linn et al., Appl. Phys. Lett., 91, 231105 (2007).

7. A.K.Chu, J.S.Wang, Z.Y.Tsai et al., Solar Ener. Mater. Solar Cells, 93, 1276 (2009).

8. H.P.Wang, K.Y.Lai, Y.R.Lin et al., Langmuir, 26, 12855 (2010).

9. S.E.Han, G.Chen, Nano Lett., 10, 4692 (2010).

10. F.Y.Wang, Q.D.Yang, G.Xu et al., Nanoscale, 3, 3269 (2011).

11. H.Lin, F.Xiu, M.Fang et al., ACS Nano, 8, 3752 (2014).

12. H.P.Wang, T.Y.Lin, M.L.Tsai et al., $A C S$ Nano, 8, 2959 (2014).

13. A.Druzhinin, V.Yerokhov, S.Nichkalo et al., J. Nano Res., 39, 89 (2016). 
14. A.Druzhinin, E.Lavitska, I.Maryamova, Sens. Actuat. B: Chem., 58, 415 (1999).

15. I.Maryamova, A.Druzhinin, E.Lavitska et al., Sens. Actuat. A: Phys., 85, 153 (2000).

16. Y.Cui, Q.Q.Wei, H.K.Park et al., Science, 293, 1289 (2001).

17. G.Zheng, F.Patolsky, Y.Cui et al., Nature Biotechn., 23, 1294 (2005).

18. J.Goldberger, A.I.Hochbaum, R.Fan et al., Nano Lett., 6, 973 (2006).

19. A.Druzhinin, I.Ostrovskii, Iu.Kogut, Mater. Scien. Semicond. Proces., 9, 853 (2006).

20. C.K.Chan, H.L.Peng, G.Liu et al., Nature Nanotechn., 3, 31 (2008).

21. A.Hochbaum, R.Chen, R.D.Delgado et al., $\mathrm{Na}$ ture, 451, 163 (2008).

22. A.Druzhinin, I.Ostrovskii, I.Kogut et al., Phys. Stat. Sol. C, 8, 867 (2011).

23. L.Tsakalakos, J.Balch, J.Fronheiser et al., J.Nanophot., 1, 013552 (2007).

24. L.Tsakalakos, J.Balch, J.Fronheiser et al., Appl.Phys. Lett., 91, 233117 (2007).

25. E.C.Garnett, P.Yang, J. Amer. Chem. Soc., 130, 9224 (2008).

26. M.D.Kelzenberg, D.B.Turner-Evans, B.M.Kayes et al., Nano Lett., 8, 710 (2008).

27. T.Stelzner, M.Pietsch, G.Andra et al., Nanotechn., 19, 295203 (2008).

28. J.Li, H.Yu, S.M.Wong et al., Appl. Phys. Lett., 95, 033102 (2009).

29. K.Q.Peng, S.T.Lee, Adv. Mater., 23, 198 (2011).
30. A.A.Druzhinin, V.Y.Yerokhov, S.I.Nichkalo et al., J. Nano. Electr. Phys., 7, 02030-1-02030-6 (2015).

31. J.Ramanujam, D.Shiri, A.Verma, Mater. Express, 1, 105 (2011).

32. X.Li, J.Li, T.Chen et al., Nanoscale Res. Lett., 5, 1721 (2010).

33. S.Nichkalo, A.Druzhinin, A.Evtukh et al., Nanoscale Res. Lett., 12, 106 (2017).

34. Z.Pei, H.Hu, S.Li et al., Langmuir, 33, 3569 (2017).

35. K.Q.Peng, Y.J.Yan, S.P.Gao et al., $A d v$. . Mater., 14, 1164 (2002).

36. Z.Huang, N.Geyer, P.Werner et al., $A d v$. Mater., 23, 285 (2011).

37. M.Pavlenko, E.L.Coy, M.Jancelewicz et al., RSC Adv., 6, 97070 (2016).

38. A.A.Druzhinin, I.P.Ostrovskii, Phys. Stat.Sol. C, 1, 333 (2004).

39. V.Schmidt, S.Senz, U.Gosele, Nano Lett., 5, 931 (2005).

40. A.Druzhinin, A.Evtukh, I.Ostrovskii et al., Springer Proc. Phys., 156, 301 (2015).

41. G.Yuan, K.Aruda, S.Zhou et al., Angew. Chem. Intern. Edit., 50, 2334 (2011).

42. B.Parida, J.Choi, G.Lim et al., J. Nanoscie. Nanotechn., 14, 9224 (2014).

43. C.Lin, M.L.Povinelli, Opt. Expr., 19, A1148 (2011).

44. H.Bao, X.Ruan, Opt. Lett., 35, 3378 (2010). 